\title{
Compensating Victims of Preferential Employment Discrimination Remedies
}

\author{
J. Hoult Verkerke
}

One of the most divisive debates in antidiscrimination law concerns the use of racial and gender preferences to remedy the effects of employment discrimination. ${ }^{1}$ In cases involving preferential remedies, ${ }^{2}$ the Supreme Court has struggled to balance the remedial interests of minorities and women against the employment expectations of dispreferred individuals. ${ }^{3}$ The Court and commentators have framed the legal dispute in terms of whether preferential remedies should be permitted." If the Court perceives a need to remedy employment discrimination that outweighs the potential for "trammeling" the interests of nonminorities, the remedy is permissi-

1. Some commentators have contended that preferential remedies should be impermissible. See, e.g., A. Bickel, The Moraltty of Consent 133 (1975) (racial quotas are "invidious in principle as well as in practice"); N. Glazer, Affirmative Discrimination: Ethnic Inequality and PuBlic PoLICy 196-97 (1975) (preferential treatment threatens to replace individual justice with statistical parity among racial and ethnic groups). Others have expressed reservations concerning the appropriate scope of such remedies. See, e.g., Fallon \& Weiler, Firefighters v. Stotts: Conflicting Models of Racial Justice, 1984 Sup. Cr. REv. 1 (developing "social justice" model of discrimination remedy attentive to effects on nonminorities). Still others have defended court-ordered and voluntary preferences. See, e.g., Black, Civil Rights in Times of Economic Stress-Jurisprudential and Philosophic Aspects, 1976 U. ILL. L.F. 559, 562 (burdens of affirmative action on whites are obligations of citizenship analogous to taxes); Carter, When Victims Happen To Be Black, 97 YALE L.J. 420, 438, 429-39 (1988) (preferential treatment justified as attempt to ameliorate "continuing victimhood of black people generally"); Fiss, Groups and the Equal Protection Clause, 5 Phil. \& PuB. Affs. 107 (1976) (group injury justifies group remedy); Kennedy, Persuasion and Distrust: $A$ Comment on the Affirmative Action Debate, 99 HARv. L. REv. 1327 (1986) (questioning motives of affirmative action critics).

2. Mirroring the substantive debate over the permissibility of preferential relief, a semantic debate rages over the proper term to describe granting preferential treatment to remedy the effects of employment discrimination. Often called "affirmative action" by advocates, critics label this form of remedy "reverse discrimination." This Note uses the descriptive term "preferential remedy" in an attempt to capture semantically the mediating tone of its substantive conclusions. See infra text accompanying note 118 .

3. As used in this Note, the term "dispreferred" refers to the class of individuals whose employment expectations are diminished by a preferential remedy. Preferential relief most often frustrates the expectations of white male employees because blacks and women bring the overwhelming majority of successful employment discrimination suits. However, when the preferred class includes only women (or blacks), black (or female) employees will be members of the dispreferred class.

4. See infra Section I. Notable exceptions to this general rule include Burke \& Chase, Resolving the Seniority/Minority Layoffs Conflict: An Employer-Targeted Approach, 13 HARv. C.R.-C.L. L. REv. 81 (1978) (advocating "full payroll" remedy for layoffs with discriminatory effect); Fallon \& Weiler, supra note 1, at 60-64 (discussing alternatives to layoffs with discriminatory effect); Case Comment, The Supreme Court, 1982 Term, 97 Harv. L. Rev. 70, 269-78 (1983); Comment, Cost Allocation in Title VII Remedies: Who Pays for Past Discrimination?, 44 TENN. L. Rev. 347 (1977). 
ble. ${ }^{5}$ However, if the remedy requires the discharge of white workers, ${ }^{6}$ creates "an absolute bar to the advancement of white employees," or is imposed "simply to create a racially balanced workforce," impermissible.

This Note does not presume to resolve the public debate concerning the legitimacy of preferential remedies. Instead, it offers another way to frame the legal issues. Rather than asking whether victims of discrimination or incumbent employees should be given an employment benefit, usually a job, this Note proposes that courts ask who should receive in-kind relief-the job-and who should receive monetary relief. The Note concludes that individuals who suffer reduced employment expectations as a result of a court-ordered preferential remedy should receive monetary compensation for their losses. ${ }^{9}$

Section I of the Note examines the permissibility debate and shows that judicially imposed limits on the scope of preferential relief result largely from a desire to protect the employment expectations of incumbent employees. Concern for the interests of dispreferreds has led courts and commentators to consider various means of compensating them for their losses. Section II analyzes these existing theories of compensation and finds them inadequate to protect the legitimate expectations of incumbent employees. Section III then presents an argument-based on statutory text, legislative history, constitutional principles, and public policy-that courts ordering preferential remedies should employ a rebuttable presumption in favor of compensating dispreferreds. Section IV outlines the implementation of compensation and considers possible objections to the proposal. The Note concludes that such systematic compensation is a promising mediating re-

5. United States v. Paradise, 480 U.S. 149, 183 (1987); Sheet Metal Workers v. EEOC, 478 U.S. 421, 479 (1986); Rutherglen \& Ortiz, Affirmative Action Under the Constitution and Title VII: From Confusion to Convergence, 35 UCLA L. Rev. 467, 468 \& n.8 (1988).

6. See, e.g., Firefighters v. Stotts, 467 U.S. 561 (1984) (burden of layoffs on nonminority employees too great to permit preferential retention of minority firefighters).

7. United Steelworkers v. Weber, 443 U.S. 193, 208 (1979). Although Weber involved only an employer's "voluntary" preference plan, its analysis of the permissible effects of preferential treatment on nonminority workers has influenced later cases considering court-ordered preferential remedies. See, e.g., Sheet Metal Workers, 478 U.S. at 479 (quoting Weber, 443 U.S. at 216, 208). Voluntary and court-ordered preferences are distinct because court-ordered preferential remedies, unlike private employers' voluntary preference plans, involve state action that triggers constitutional equal protection scrutiny. Furthermore, courts analyze voluntary plans under the antidiscrimination provisions of Title VII, 42 U.S.C. $\$ 2000 \mathrm{e}-2$ (a) (1982). Court-ordered preferential relief is analyzed principally under the remedial sections, 42 U.S.C. $\$ \S 2000 \mathrm{e}-5(\mathrm{~g}), 2000 \mathrm{e}-2(\mathrm{j})$. See also infra note 9 (discussing extension of this Note's argument to voluntary preference plans and consent decrees).

8. Sheet Metal Workers, 478 U.S. at 475.

9. Although it is beyond the scope of this Note to consider consent decrees, labor contracts, or unilateral employer actions granting preferential treatment for minority and female employees, many of the arguments supporting compensation for the effects of court-ordered preferential remedies apply to these other contexts. In the case of consent decrees, compensation analogous to this Note's proposed remedy could be required as a condition for judicial approval of the decree. Compensation for the effects of contractual and unilateral preference plans could be awarded to dispreferred individuals in an independent Title VII action. 
sponse to the deep conflicts of interests and ideals concerning preferential remedies.

\section{The Permissibility Debate: Employment Expectations as a Constraint on Preferential Relief}

In debating the permissibility of preferential relief under Title VII of the Civil Rights Act of $1964,{ }^{10}$ the Supreme Court has, at various times, endorsed make-whole relief for victims of discrimination, ${ }^{11}$ the broad goal of ensuring equal employment opportunity for traditionally excluded groups, ${ }^{12}$ and the protection of the legitimate employment expectations of incumbent employees. ${ }^{13}$ Despite the inconsistency of its doctrinal development, one feature of the Court's employment discrimination jurisprudence is clear: The employment expectations of dispreferred individuals are a significant constraint on the use of preferential remedies.

In order to award preferential relief, a trial court must first find that an employer or union engaged in unlawful discrimination. Section 703 of Title VII, which defines unlawful employment practices, expresses a broad congressional objective to prohibit employment decisions from being made on the basis of race or gender. ${ }^{14}$ The Supreme Court has translated this general statutory prohibition into the two basic theories of liability under Title VII: disparate impact ${ }^{25}$ and disparate treatment. ${ }^{16}$

Once liability has been determined, section 706(g) of Title VII confers on courts broad discretion to order-

10. Pub. L. No. $88-352,78$ Stat. $253-66$ (current version at 42 U.S.C. $\S \S 2000$ e to 2000 e- 17 (1982)).

11. Franks v. Bowman Transp. Co., 424 U.S. 747, 764 (1976) ("[F]ederal courts are empowered to fashion such relief as the particular circumstances of a case may require to effect restitution, making whole insofar as possible the victims of racial discrimination in hiring.").

12. Sheet Metal Workers, 478 U.S. at 448 ("[R]ace-conscious affirmative relief . . . furthers the broad purposes underlying [Title VII] . . . to achieve equality of employment opportunities and remove barriers that have operated in the past to favor an identifiable group of white employees over other employees.' ") (quoting Griggs v. Duke Power Co., 401 U.S. 424, 429-30 (1971)).

13. Firefighters v. Stotts, 467 U.S. 561, 575 (1984) ("[I]t is inappropriate to deny an innocent employee the benefits of his seniority in order to provide a remedy in a pattern-or-practice suit such as this.").

14. Section 703(a) provides:

It shall be an unlawful employment practice for an employer-

(1) to fail or refuse to hire or to discharge any individual, or otherwise to discriminate against any individual with respect to his compensation, terms, conditions, or privileges of employment, because of such individual's race, color, religion, sex, or national origin; or

(2) to limit, segregate, or classify his employees or applicants for employment in any way which would deprive or tend to deprive any individual of employment opportunities or otherwise adversely affect his status as an employee, because of such individual's race, color, religion, sex, or national origin.

42 U.S.C. § 2000e-2(a) (1982); see also 42 U.S.C. § 2000e-2(b), (c) (1982) (parallel prohibitions for employment agencies and labor organizations).

15. Albemarle Paper Co. v. Moody, 422 U.S. 405, 425 (1975). For the original statement of the disparate impact theory, see Griggs v. Duke Power Co., 401 U.S. 424 (1971).

16. Texas Dep't of Community Affairs v. Burdine, 450 U.S. 248, 255-60 (1981). For the original statement of the disparate treatment theory, see McDonnell Douglas Corp. v. Green, 411 U.S. 792 (1973). 
such affirmative action as may be appropriate, which may include, but is not limited to, reinstatement or hiring of employees, with or without back pay (payable by the employer, employment agency, or labor organization, as the case may be, responsible for the unlawful employment practice), or any other equitable relief as the court deems appropriate. ${ }^{17}$

The broad language of $\S 706(\mathrm{~g})$ fails to specify what sort of remedy is "appropriate" and "equitable."18 Moreover, no section of Title VII states explicitly when preferential relief is permissible.

Perhaps because of this statutory vagueness, the Supreme Court has struggled to define the permissible scope of trial court discretion. The Gourt reviews court-ordered preferential remedies under both Title VII and the equal protection component of the due process clause ${ }^{19}$ because they involve a federal court-a state actor-acting under the remedial authority of section $706(\mathrm{~g})$. The Court has generally upheld the use of courtordered preferential relief. ${ }^{20}$ However, it has consistently held that the degree to which preferential remedies frustrate the legitimate employment expectations of dispreferred individuals is relevant to the permissible scope of such relief under section $706(\mathrm{~g}) .^{21}$

Although the doctrinal language of statutory and constitutional decisions differs slightly, the Court applies what is essentially a two-pronged test-considering both the burden preferences impose on dispreferreds and the justification for the remedy-to determine when preferential relief is

17. 42 U.S.C. $§ 2000 \mathrm{e}-5(\mathrm{~g})$ (1982) (emphasis added). The emphasized language is part of the Equal Employment Opportunity Act of 1972 amendments to Title VII. Pub. L. No. 92-261, 86 Stat. 103-13. One limitation on the scope of remedies is a provision in $\$ 706(\mathrm{~g})$ excluding from affirmative relief (such as hiring or promotion) any individual who "was refused employment or advancement or was suspended or discharged for any reason other than discrimination." 42 U.S.C. $\$ 2000 \mathrm{e}-5(\mathrm{~g})$ (1982). Although some have argued that this sentence prohibits preferential relief that benefits nonvictims, courts generally have interpreted it as only prohibiting a court from ordering affirmative relief in favor of unqualified individuals. See Sheet Metal Workers v. EEOC, 478 U.S. 421, 473-75 (rejecting contention that $\S 706(\mathrm{~g})$ limits relief to proven victims of discrimination); Firefighters v. Stotts, 467 U.S. 561, 617-18 (1984) (Blackmun, J., dissenting) (collecting cases).

18. Section 703(j) of Title VII provides that "[n]othing contained in this title shall be interpreted to require any employer . . . to grant preferential treatment to any individual or group on account of an imbalance" between the percentage of persons of any race or gender employed and the percentage of persons of that race or gender in the available work force. 42 U.S.C. $\$ 2000 \mathrm{e}-2(j)$ (1982). Some have argued that $\$ 703(j)$ prohibits preferential relief to individuals who are not proven victims of discrimination. See, e.g., Sheet Metal Workers v. EEOC, 478 U.S. 421, 491-99 (1986) (O'Connor, $\mathrm{J}$., concurring in part and dissenting in part) ("IT]he words 'Nothing contained in this title shall be interpreted to require' plainly make $\$ 703(j)$ applicable to the interpretation of any provision of Title VII, including $\$ 706(\mathrm{~g})$."). The Court has rejected this argument. Id. at 464 n.37.

19. U.S. Consi: amend. V, cl. 3.

20. United States v. Paradise, 480 U.S. 149 (1987) (preference in promotion); Sheet Metal Workers, 478 U.S. 421 (union membership goal); Franks v. Bowman Transp. Co., 424 U.S. 747 (1976) (retroactive seniority).

21. For the purposes of this Note, a "legitimate employment expectation" is an employee's expectation of being hired, trained, promoted, or retained that is not tainted by personal involvement in discriminatory practices. See infra note 118 (discussing consequences of employee involvement in discriminatory practices). 
permissible. ${ }^{22}$ The Court's desire to protect employment expectations has most clearly determined the development of the burden prong of the permissiblity test. In the oft-quoted formulation of United Steelworkers $v$. Weber, preferences are impermissible if they "require the discharge of white workers and their replacement with new black hirees. ... [or] create an absolute bar to the advancement of white employees."23 For example, the Court has twice held that preferential protection against senioritybased layoffs imposes an impermissible burden on dispreferred incumbent employees. ${ }^{24}$

In Firefighters $v$. Stotts, ${ }^{25}$ the Court reviewed a district court's preliminary injunction that had been entered against seniority-based layoffs. The district court issued the order to prevent the layoffs from eliminating gains in minority representation that had been made under a consent decree. The Supreme Court concluded that the district court, even after a finding of discrimination, could not have ordered a remedy that would displace incumbent employees. ${ }^{28}$ In modifying a consent decree that contained no admission of discrimination, a bumping order was a fortiori impermissible. ${ }^{27}$ The need to protect the expectations of incumbent employees was a decisive consideration. Justice White's majority opinion stated flatly that "[i]t is inappropriate to deny an innocent employee the benefits of his seniority in order to provide a remedy." ${ }^{28}$ In her separate concurrence, Justice O'Connor echoed the view that the district court could not "unilat-

22. Rutherglen \& Ortiz, supra note 5 , at $468 \&$ n.8 ("Almost from the start, the justices have agreed that both the statutory and constitutional analyses of preferences should focus on two factors: the burden a preference plan places on innocent employees, usually white, and the justification for a preference as a remedy for past discrimination."). Although the constitutional and statutory standards for court-ordered preferential relief are quite similar, the Court appears to apply a more lenient standard to voluntary preference plans than it applies to court-ordered preferential remedies. Compare Johnson v. Transportation Agency, 480 U.S. 616 (1987) (voluntary preference in promotion reviewed under Title VII) with United States v. Paradise, 480 U.S. 149 (1987) (court-ordered preference in promotion reviewed under Constitution). See generally Rutherglen \& Ortiz, supra note 5, at 471 (suggesting that distinction between voluntary and court-ordered preference plans should supplant distinction between statutory and constitutional standards).

23. 443 U.S. 193, 208 (1979). Even before the Weber decision, lower courts had held that relief could not permissibly include bumping incumbent employees out of their present jobs. See, e.g., Patterson v. American Tobacco Co., 535 F.2d 257, 267 (4th Cir.), cert. denied, 429 U.S. 920 (1976); United Papermakers and Paperworkers v. United States, 416 F.2d 980, 988 (5th Cir. 1969), cert. denied, 397 U.S. 919 (1970).

24. Wygant v. Jackson Bd. of Educ., 476 U.S. 267 (1986); Firefighters v. Stotts, 467 U.S. 561 (1984). In I'ygant, Justice Powell's plurality opinion expressly relied on the fact that preferential layofi protection disrupts the "settled expectations" of incumbent employees. Such a frustration of employment expectations "imposes the entire burden of achieving racial equality on particular individuals, often resulting in serious disruption of their lives." 476 U.S. at 283.

25. 467 U.S. 561 (1984).

26. Id. at 579 . The order would have displaced incumbent workers by requiring the Fire Department to lay off nonminority firefighters with greater seniority instead of more recently hired minority firefighters.

27. Id.

28. Id. at 575 . 
erally modify a consent decree ... to provide retroactive relief that abrogates legitimate expectations" of incumbent employees. ${ }^{29}$

In addition to their direct effect on the burden prong, employment expectations have also influenced the justification prong of the permissibility test. First, the Court has created a fundamental doctrinal distinction between make-whole relief, to which only proven victims of discrimination are presumptively entitled, and prospective relief, which may benefit nonvictims. ${ }^{30}$ This distinction has meant that the more complete makewhole relief, which is also more likely to upset the expectations of incumbent employees, requires a higher level of justification. ${ }^{31}$

In its most recent case considering the permissibility of preferential remedies, United States $v$. Paradise, ${ }^{\mathbf{3 2}}$ the Court upheld a promotional preference order designed to remedy "pervasive, systematic, and obstinate discriminatory conduct ... [that] created a profound need and a firm justification for the race-conscious relief ordered by the District Court." ${ }^{33}$ Applying strict scrutiny to this racial classification, Justice Brennan, in his plurality opinion, admitted that the district court's discretion in remedying this egregious discrimination "was limited by the rights and interests of the white troopers seeking promotion to corporal." that the balance must be struck in favor of the preferential remedy.

The dissenters concluded that the effects of the promotional preference plan on nonminority firefighters rendered it impermissible. Justice O'Connor argued that the promotional "goal" was not sufficiently "narrowly tailored." 35 In her view, strict scrutiny required "the most exact

29. Id. at 587 (O'Connor, J., concurring). Even in cases upholding preferential remedies, all of the Justices have acknowledged the importance of employment expectations in defining the permissible burden on dispreferreds. For example, in Sheet Metal Workers v. EEOC, 478 U.S. 421 (1986), Justice Brennan considered it "significant" that the union membership goal imposed by the trial court did not "unnecessarily trammel the interests of white employees." Id. at 479 . Justice O'Connor objected that "the membership goal operates as a rigid membership quota, which will in turn spawn a sharp curtailment in the opportunities of nonminorities to be admitted to the apprenticeship program." Id. at 498 (O'Connor, J., concurring in part and dissenting in part). Despite their obvious differences in emphasis, both the majority and dissenters agreed that the employment expectations of dispreferred individuals were directly relevant to the permissibility of the preferential remedy.

30. Compare Franks v. Bowman Transp. Co., 424 U.S. 747, 764 (1976) and Sheet Metal Workers, 478 U.S. at $445,482$.

31. The Court has also required a compelling justification for prospective preferential relief awarded to nonvictims. For example, in Sheet Metal Workers, the Court upheld a union membership goal and held that "persistent or egregious discrimination" or a need to "dissipate the lingering effects of pervasive discrimination" constituted sufficient warrant for preferential relief. 478 U.S. at 445 . The Court, despite its endorsement of prospective preferential relief, relied heavily on the determination that such relief was necessary to remedy the union's egregious discrimination.

32. 480 U.S. 149 (1987). Although Paradise involved a remedy for violations of the equal protection clause rather than Title VII, it provides further insight into the importance of dispreferreds' employment expectations in limiting preferential relief. In his concurrence, Justice Powell suggested that the standards for review under Title VII and equal protection analysis are "similar" though not necessarily identical. Id, at $186 \mathrm{n} .1$ (Powell, J., concurring).

33. Id. at 167.

34. Id. at 185 .

35. 480 U.S. at 197 (O'Connor, J., dissenting). Chief Justice Rehnquist and Justice Scalia joined Justice O'Connor's dissent, and Justice White indicated his substantial agreement with her opinion. 
connection between justification and classification"36 to protect nonminority employees from all but absolutely necessary uses of racial preferences. Despite an admittedly compelling government interest in remedying such egregious discrimination, both the majority and dissenting opinions agreed that the competing interests of nonminority workers required searching scrutiny of the means employed to achieve that end. ${ }^{37}$

\section{Existing Theories of Compensation to DispreferRedS}

Both critics and advocates of preferential remedies view the effects of preferences on dispreferred individuals as a decisive factor in determining the permissibility of such remedies. It is, therefore, not surprising that commentators have proposed various means of protecting the interests of dispreferreds, and that some courts have explored ways to share remedial costs among discrimination victims, incumbent employees, and employers.

\section{A. Equitable Discretion Under Section 706(g)}

The trial court's broad remedial discretion under section 706(g) clearly includes the power to order an employer to pay compensation or to take other action to protect the expectations of dispreferreds. ${ }^{38}$ In Franks $v$. Bowman Transportation Co. ${ }^{39}$ both the majority and dissenting opinions briefly discussed the potential claims of dispreferred individuals. Justice Brennan characterized the Court's holding as establishing "a sharing of the burden of the past discrimination," and left open the "possibility of an injunctive 'hold harmless' remedy respecting all affected employees in a layoff situation, [and] the possibility of an award of monetary damages (sometimes designated 'front pay') in favor of each employee and discriminatee otherwise bearing some of the burden of the past discrimination." ${ }^{30}$ The Court did not foreclose employees who are injured by preferential remedies from seeking equitable relief on their own behalf. ${ }^{41}$

Several other cases suggest the possible application of equitable discretion to the problems of preferential relief. For example, in Watkins $v$. United Steel Workers, ${ }^{\mathbf{4}}$ the district court ordered an employer to recall laid-off black workers in order to restore a prescribed racial ratio. However, the court also ordered that the reinstatements take place with "the

36. Id. at 199 (quoting Fullilove v. Klutznick, 448 U.S. 448, 537 (1980) (Stevens, J., dissenting)).

37. Although the Court has not resolved whether a lesser justification than "egregious and longstanding" discrimination might be sufficient, Justice Kennedy's concurrence in City of Richmond $v$. J.A. Croson Co., 109 S. Ct. 706 (1989), suggests that court-ordered racial preferences will face "the most rigorous scrutiny." Id. at 734 .

38. The plain language of the section vests the court with the full powers of an equity court to fashion complete relief. See supra notes 17-18 and accompanying text.

39. 424 U.S. 747 (1976).

40. Id. at $777 \&$ n.38 (citation omitted).

41. Id. at 777 n.38; id. at 781 (Burger, C.J., dissenting).

42. 369 F. Supp. 1221 (E.D. La. 1974), rev'd on other grounds, 516 F.2d 41 (5th Cir. 1975). 
minimum alteration of existing industrial practices that is consistent with redressing the discrimination present here." ${ }^{\prime 3}$ Although the court deferred decision on a specific remedial order, it suggested that the company rather than "a few white employees" should bear the costs of remedying the unlawful discrimination. One way of allocating the costs, the court concluded, would be to require the employer to retain a larger work force "until normal attrition reduces the work force to its most efficient level."44

In the context of promotions, a district court in Patterson v. American Tobacco Co. ${ }^{45}$ ordered that employers who bumped whites back to lower level jobs to make room for discrimination victims should continue to pay these white employees their previous wages. ${ }^{46}$ These unorthodox remedial measures were reversed on appeal not because of provisions protecting dispreferred workers, but rather because the preferential relief itself was impermissible. ${ }^{47}$ Curiously, the use of the trial court's equitable powers to mitigate the effects of preferential relief on dispreferreds has largely disappeared from the doctrinal landscape of employment discrimination law. ${ }^{48}$

\section{B. Cause of Action Under Title VII}

Just two months after the Supreme Court decided Franks, a district court, in McAleer v. AT \& $T,{ }^{48}$ ordered AT \& $\mathrm{T}$ to compensate a male employee who had been passed over for promotion in favor of a lessqualified junior female employee. The company had acted pursuant to the terms of a consent decree providing promotional preferences for women and minorities to rectify violations of Title VII. The district court reasoned that although an identifiable victim of discrimination may benefit from preferential relief designed to eradicate the employer's discrimination, Franks compelled the court to "plac[e] this burden on the wrongdoing employer whenever possible." McAleer stated a cause of action under Title VII for monetary damages but not for injunctive relief. ${ }^{31}$

43. Id. at 1232 .

44. Id.

45. 8 Fair Empl. Prac. Cas. (BNA) 778 (E.D. Va. 1974), rev'd on other grounds, 535 F.2d 257 (4th Cir.), cert. denied, 429 U.S. 920 (1976).

46. Id. at 784 .

47. Patterson v. American Tobacco Co., 535 F.2d 257, 267-69 (4th Cir.), cert. denied, 429 U.S. 920 (1976); Watkins v. United Steelworkers, 516 F.2d 41, 44-45 (5th Cir. 1975).

48. Writing in 1978, Professors Iris Burke and Oscar Chase lamented the failure of courts and commentators to consider alternatives to the "displacement remedy." See Burke \& Chase, supra note 4 , at $83,89,94-95$. Since their article was published, there has been no sustained judicial or academic consideration of the potential role of equity in mitigating the losses of dispreferreds. But see infra Sections III \& IV (arguing that to be "equitable" within language of $\S 706(\mathrm{~g})$, remedies must include provisions for compensating dispreferred individuals).

49. 416 F. Supp. 435 (D.D.C. 1976).

50. Id. at 439 .

51. Id. at $439-40$. 
McAleer reached the right result for the wrong reasons and in the wrong forum. Since Daniel McAleer challenged company actions that had been taken to comply with a preexisting consent decree, his claims should have been heard in the court that entered the decree and retained jurisdiction. ${ }^{52}$ Moreover, in light of subsequent Supreme Court decisions, the court in McAleer concluded erroneously that the promotional preference was a violation of Title VII. ${ }^{53}$ The district court's theory of liability for preferential treatment is inconsistent with both Weber, ${ }^{84}$ in which the Court upheld a "voluntary" preference plan, and Firefighters v. Cleveland ${ }^{\mathrm{Bb}}$ in which the Court applied a similarly liberal standard of review for preferential treatment pursuant to consent decrees. These later decisions essentially foreclose further use of McAleer's theory of compensation.

Despite these doctrinal shortcomings, the court properly sought to reallocate the costs of remedying employment discrimination from the incumbent employee to the culpable employer. McAleer provides an isolated example of a court recognizing that monetary compensation to dispreferreds is an equitable remedy separable from a prohibitory injunction against the operation of the promotional preference plan.

\section{Full Payroll Remedy}

In the specific context of conflicts between seniority rights and the right of successful plaintiffs to protection from seniority-based layoffs, Professors Iris Burke and Oscar Chase have proposed that courts employ a "full payroll" remedy. ${ }^{58}$ The full payroll remedy requires an employer wishing to make layoffs to retain both minority and nonminority employees on

52. See, e.g., Thaggard v. City of Jackson, 687 F.2d 66 (5th Cir. 1982) (barring collateral attack on consent decree even though plaintiffs had tried unsuccessfully to intervene in original suit), cert. denied sub nom., Ashley v. City of Jackson, 464 U.S. 900 (1983). But see Ashley v. City of Jackson, 464 U.S. 900 (1983) (Rehnquist, J., dissenting from denial of cert.) (arguing forcefully that established principles of res judicata and due process protect right to sue where consent decree was entered before plaintiff 's cause of action accrued); Comment, Collateral Attacks on Employment Discrimination Consent Decrees, 53 U. CHI. L. REv. 147 (1986) (criticizing reasoning of Thaggard). Even if McAleer's theory of compensation were accepted for consent decrees, courts are far more reluctant to permit collateral attacks on court orders. See, e.g., Black \& White School Children v. School Dist. of Pontiac, 464 F.2d 1030, 1030 (6th Cir. 1972) ("The proper avenue for relief . . . [is] an application to intervene and a motion for additional relief in the principal case.").

53. At least one contemporary commentator questioned the reasoning of the district court's opinion. See Comment, supra note 4, at 370-74.

54. 443 U.S. 193 (1979).

55. 478 U.S. 501 (1986).

56. Burke \& Chase, supra note 4. This Note's "systematic compensation" proposal, in its effort to force employers to bear the costs of remedying their employment discrimination, resembles the full payroll approach. However, this Note's proposal is more ambitious than the full payroll approach. While Burke and Chase consider only the clash between contractual seniority rights and "massive lajoffs that wiped out many of the recent gains of minority workers," id. at 82 (emphasis added) (footnote omitted), this Note argues that noncontractual employment expectations are also entitled to protection, and the Note's proposed remedy is equally applicable to preferential treatment in other areas of the employment relationship, including training and promotion. 
full-time payroll, unless the costs of retaining them will cause the financial collapse of the firm. ${ }^{\text {.7 }}$

Burke and Chase argued that the displacement remedy poorly allocates the cost of remedying discrimination. First, displacement remedies fail to impose the cost of the remedy on employers. Instead, they place the burden of the remedy "exclusively on the employees, both black and white, although neither is responsible for the discrimination," moral principle that "the wrongdoer should bear the cost of relief." authors' second objection was to the burden that the displacement remedy imposes on white workers. Foregoing other employment opportunities, these employees rely in good faith on a seniority system for job security. According to the authors, depriving majority workers of this protection for the benefit of minorities is likely to exacerbate racial tensions and resentment "in the blue collar neighborhoods that experience industrial slowdowns acutely."

The full payroll remedy does address one of the major objections to preferential protection against layoffs: the potentially serious burden such preferences impose on dispreferred individuals. However, despite its intuitive appeal, the full payroll approach has several important defects and has not been used widely. ${ }^{61}$ First, Burke and Chase considered only conflicts between seniority and an employer's need to make layoffs. Steadily falling unemployment rates since 1983 have rendered this conflict less frequent than it was during the period of high unemployment in the late 1970's and early 1980's. ${ }^{62}$ Moreover, the Supreme Court has struck down recent attempts to use preferences that require an employer to lay off dispreferred incumbent employees. ${ }^{\mathbf{6}}$ If such layoff protection is impermissible, the full payroll approach is no longer applicable to any permissible form of preferential relief. ${ }^{84}$

57. Id. at 111-15 (describing "standard of impending insolvency").

58. Id. at 88 .

59. Id. at 90. These moral views also accord with the deterrent objective of Title VII and statutory language indicating who should pay for relief. Id. at 91 . Section $706(\mathrm{~g})$ specifies that backpay should be paid by the party "responsible for the unlawful employment practice." 42 U.S.C. \$2000e5(g) (1982). Moreover, the Supreme Court has identified deterrence of unlawful discrimination as an important objective of imposing backpay liability. Albemarle Paper Co. v. Moody, 422 U.S. 405, 417 (1975).

60. Id. at 94 .

61. Only one reported federal case, Stotts v. Memphis Fire Dept., 679 F.2d 579, 589 (6th Cir. 1982) (Martin, J., dissenting), cites Burke \& Chase.

62. The civilian unemployment rate has fallen from its peak of $9.5 \%$ in $1982-83$ to $5.3 \%$ in 1988 . U.S. Dept. of CoMmerce, BuREaU of Labor Statistics, EMPloyment and Earnings (1988).

63. See Wygant v. Jackson Bd. of Educ., 476 U.S. 267 (1986); Firefighters v. Stotts, 467 U.S. 561 (1984).

64. Burke and Chase also neglected several important legal arguments for compensation to dispreferreds. In particular, they failed to consider the nexus between the antidiscrimination provisions of $\S 703$ and the meaning of "equitable" remedies in $\S 706(\mathrm{~g})$; they also did not explore constitutional equal protection arguments for compensation. See infra Sections III(A)-(C) (presenting statutory and constitutional arguments requiring compensation). Finally, the policy arguments Burke and Chase offered in support of their proposed remedy dealt only with the desirability of shifting remedial costs 


\section{Contractual Damages}

Although the equitable discretion, independent cause of action, and full payroll theories have failed to influence the Supreme Court's doctrine, the Court has unanimously embraced a contract theory of compensation to dispreferred employees. In W.R. Grace $\mathcal{E}^{2}$ Co. v. Local Union $759,{ }^{65}$ the company, while acting pursuant to a conciliation agreement with the Equal Employment Opportunity Commission, had breached its collective bargaining agreement by laying off several male employees. The Court unanimously upheld an arbitrator's award of damages to the male employees. When preferential relief violates employees' explicit contractual rights, the Court held that they may recover damages for the breach under the law governing the contract without violating the public policies of Title VII. ${ }^{8 B}$

However, the holding was based entirely on the enforceability of the arbitration award as a matter of contractual interpretation. ${ }^{67}$ Although the Supreme Court endorsed the principle that an employer may not unilaterally breach a collective bargaining agreement in order to avoid suit under Title VII, this contract theory applies only to situations in which a dispreferred employee has an enforceable contractual claim against his employer. For example, a contract theory of compensation fails to protect dispreferred employees whose company has an unwritten policy of deciding promotions based on merit and seniority ${ }^{68}$ Since Title VII is best understood as affirmatively regulating the employment relationship instead of simply enforcing preexisting arrangements, ${ }^{69}$ a contract theory should not exhaust the protections available to dispreferred employees. ${ }^{70} \mathrm{It}$

from dispreferreds to the employer. They neglected entirely the distribution of remedial costs among dispreferred individuals. See infra Sections III(D)-(E) (examining incidence of burdens of preferential remedies in relation to justice and deterrence).

65. 461 U.S. 757 (1983).

66. Although W.R. Grace involved a conciliation agreement providing for preferential treatment, such a contract remedy might also be available in the case of court-ordered preferential relief. A federal district court ordering preferential relief could properly assert pendent jurisdiction over the state Jaw contract claims of dispreferreds. United Mine Workers v. Gibbs, 383 U.S. 715, 725 (1965)

("The state and federal claims must derive from a common nucleus of operative fact.").

67. W.R. Grace, 461 U.S. at 764 ("The sole issue before the Court is whether the Barrett award should be enforced.").

68. But see infra note 71 and accompanying text (discussing developments in implied contract doctrine).

69. Rutherglen \& Ortiz, supra note 5 , at 473.

70. An imaginative district court has suggested a somewhat more tenuous theory of compensation based on a constitutional "takings" analysis. Vulcan Pioneers, Inc. v. New Jersey Dep't of Civil Serv., 588 F. Supp. 716, vacated, 588 F. Supp. 732 (1984). The court characterized the imposition of preferences pursuant to a consent decree with the United States government as a "taking." Id. at 718 .

This takings clause theory of compensation is suspect because, in addition to grave problems in characterizing the government's action in entering a consent decree as a taking, there is no reason to suppose that the government rather than the employer is the appropriate party to bear the costs of compensation. See Fallon and Weiler, supra note 1, at 63 n.235. Culpable private and public employers should not be able to reallocate remedial costs by entering a consent decree with the government. Furthermore, many legitimate employment expectations do not rise to the level of property interests and therefore would be uncompensable under the takings clause theory. 
is also important to note that Title VII is federal legislation that supplements, even though it does not preempt, state contract law. ${ }^{71}$ Finally, the uniform application of federal law is another reason to provide consistent and systematic compensation within the federal remedial system.

\section{Systematic Gompensation Under Title VII}

Systematic compensation to dispreferred individuals is essential to an equitable system of Title VII remedies. To cure the defects of existing theories of compensation, the Supreme Court should create a rebuttable presumption in favor of awarding monetary compensation to the victims of preferential remedies. Just as the Court has constrained trial court discretion in awarding backpay and retroactive seniority, ${ }^{72}$ it should demand that preferential remedies ordered under Title VII either include compensation to dispreferreds or explain why such compensation is not feasible.

\section{A. Statutory Language and the Meaning of "Equitable Relief"}

The nexus between the antidiscrimination provisions of section 703 and the equitable discretion conferred by section $706(\mathrm{~g})$ provides a firm statutory basis for compensating dispreferreds. Section 706(g) of Title VII empowers the trial court to grant such "equitable relief as [it] deems appropriate." ${ }^{33}$ In determining what form of remedy is "appropriate" and "equitable," the court should look to the blanket prohibition of racial and gender classifications contained in section 703 . The statute clearly expresses a strong policy against practices tending to diminish any individual's privileges of employment because of her race or gender. ${ }^{74}$ In light of this policy, an equitable remedy under section $706(\mathrm{~g})$ should include any feature tending to diminish race- or gender-based effects that does not frustrate the basic purpose of the remedy. Compensation to dispreferred individuals would significantly ameliorate the financial burden of prefer-

71. To the extent that state contract law is inconsistent with the federal court's interpretation of Title VII, the state law is preempted. 42 U.S.C. $\$ 2000 \mathrm{e}-7$ (1982). In addition, state law would be preempted if Congress had displayed an intent to occupy the field of conflict. See Rice v. Santa Fe Elevator, Inc., 331 U.S. 218 (1947); see also Schneidewind v. ANR Pipeline Co., 108 S. Ct. 1145, 1150 (1988) ("Congress implicitly may indicate an intent to occupy a given field to the exclusion of state law."). No court has found such an intent to preclude the operation of state contract law.

Even without systematic compensation, dispreferred employees may be able to turn to the developing body of state law on implied employment contracts. These doctrines have developed largely to mitigate a perceived harshness of the traditional doctrine of employment-at-will. See, e.g., Grouse v. Group Health Plan, Inc., 306 N.W.2d 114 (1981) (reliance damages available even though contract was terminable at will).

72. See Franks v. Bowman Transp. Co., 424 U.S. 747 (1976); Albemarle Paper Co. v. Moody, 422 U.S. 405 (1975); see also Belton, Harnessing Discretionary Justice in the Employment Discrimination Cases: The Moody and Franks Standards, 44 Orro ST. L.J. 571, 572-73 (1983) (Supreme Court has significantly constrained traditional notions of equitable discretion in area of employment discrimination remedies).

73. 42 U.S.C. $\S 2000 \mathrm{e}-5(\mathrm{~g})(1982)$.

74. See supra notes 14-16 and accompanying text (discussing liability provisions of Title VII). 
ential remedies. Moreover, the same section of the statute directs that damages should be paid by the party "responsible for the unlawful employment practice."7s This explicit statutory directive identifying the proper party to bear remedial costs coupled with the nexus between the antidiscrimination provisions of section 703 and the remedial provisions of section $706(\mathrm{~g})$ should shape the meaning of equity under the statute.

\section{B. Legislative Intent}

Title VII's legislative history strongly suggests that Congress intended to vest the federal courts with broad remedial discretion-broad enough to include the power to compensate dispreferred individuals. To be sure, the 88th Congress did not consider the narrow question of whether dispreferred employees should receive compensation when it drafted Title VII. ${ }^{76}$ However, the legislators took affirmative steps to reduce the impact on incumbent employees of the effort to eradicate employment discrimination. For example, the statute explicitly protects the exercise of bona fide seniority rights and approves merit-based selection procedures. ${ }^{77}$

This legislative concern for protecting existing expectations lends limited support to interpreting Title VII to include protection for the employment expectations of nonminority employees. ${ }^{78}$ Moreover, there is no evidence that Congress intended to prevent courts from awarding compensation to nonminority individuals under Title VII. In fact, Congress affirmatively delegated to the federal courts the task of developing an equitable system of remedies. ${ }^{79}$ In defining appropriate relief, courts may

75. 42 U.S.C. $\$ 2000 \mathrm{e}-5(\mathrm{~g})(1982)$.

76. Congress's failure to consider this issue is not surprising since there was also no consideration of the use of preferential remedies. See Sheet Metal Workers v. EEOC, 478 U.S. 421, 463-64 (1986) (explaining that "the use of racial preferences as a remedy for past discrimination simply was not an issue at the time Title VII was being considered"). See generally Vaas, Title VII: Legislative History, 7 B.C. IND. \& Com. L. REv. 431 (1965) (reviewing debates).

During the debates over the Equal Employment Opportunity Act of 1972, Senator Ervin introduced two amendments, directed primarily against racial preferences required under Executive Order 11246, which also would have outlawed court-ordered preferential remedies. Both of these amendments were defeated. 118 Cong. Rec. 1676, 4918 (1972). To the extent that this action suggests that Congress sought to protect the discretion of courts to order preferential relief, it reinforces the view that compensation to dispreferreds would also be within this discretionary authority.

77. 42 U.S.C. $\$ 2000 \mathrm{e}-2(\mathrm{~h})$ (1982); see Teamsters v. United States, 431 U.S. 324, 353-54 (1977) ("[A]n otherwise neutral, legitimate seniority system does not become unlawful under Title VII simply because it may perpetuate pre-Act discrimination.").

78. Senators Clark and Case, the bipartisan floor captains of Title VII, issued an interpretive memorandum in which they asserted unequivocally that "Title VII would have no effect on established seniority rights." 110 CoNG. REc. 7213 (1964). The House Judiciary Committee's Report emphasized the legislators' view that the "primary" purpose of Title VII would be "to make certain that the channels of employment are open to persons regardless of their race and that jobs in companies or membership in unions are strictly filled on the basis of qualifications." H.R. REP. No. 914, 88th Cong., 1st Sess. (1963), reprinted in 2 U.S. Code Cong. \& AdmIN. News 2391, 2516 (1964).

79. This grant of general remedial authority reflected the belief of some members of Congress that the federal judiciary was the proper forum in which to determine equitable relief from discriminatory employment practices. H.R. REP. No. 914, 88th Cong., 1st Sess. (1963), reprinted in 2 U.S. CODE Cong. \& Admin. News 2391 (1964), ("A substantial number of committee members . . preferred 
legitimately rely on equitable and policy considerations extrinsic to the text of the statute.

\section{G. Constitutional Constraints on Permissible Remedies}

The equal protection component of the due process clause imposes important constraints on a court's remedial discretion. The Supreme Court's recent decision in City of Richmond v. J.A. Croson, striking down the city's minority set-aside program for contractors, establishes unequivocally that a majority of the justices will apply strict scrutiny ${ }^{80}$ to forbid "the use of even narrowly drawn racial classifications except as a last resort." The strict scrutiny test demands that the racial classification be "narrowly tailored"82 to achieve a "compelling [governmental] interest." cation of this standard to preferential remedies provides an independent ground for demanding compensation to dispreferreds. ${ }^{84}$

There can be no dispute that eradicating employment discrimination is a compelling government interest. ${ }^{85}$ But the Court is often divided over the degree to which preferential remedies satisfy the constitutional requirement that the means be narrowly tailored. ${ }^{86}$ The question is indeed a difficult one if the trial court must choose to order either preferential relief without compensation, monetary relief solely for victims of discrimination, or-if no victims of discrimination come forward-no remedy at all. However, compensation to dispreferreds raises the less stark question of whether compensation will so interfere with achieving the government's remedial purpose that a narrowly tailored remedy properly excludes compensation. A rebuttable presumption that compensation is required would properly balance the goal of equal protection against a trial court's practical need for flexibility.

that the ultimate determination of discrimination rest with the Federal Judiciary.") (Additional Views on H.R. 7152 of Hon. William M. McCulloch et al.). No legislative commentary on this delegation suggests a congressional intent to eliminate monetary compensation to dispreferreds from the scope of "appropriate" and "equitable" relief under $\$ 706(\mathrm{~g})$ of Title VII.

80. 109 S. Ct. 706, 721 (O'Connor, J., joined by Rehnquist, C.J., White and Kennedy, JJ.); id. at 735 (Scalia, J., concurring in judgment).

81. Id. at 734 (Kennedy, J., concurring).

82. Id. at 728 .

83. Id. at 727 .

84. Although the Court applies intermediate, rather than strict, scrutiny to gender classifications, there is a firm constitutional basis for challenging classifications that reduce employment prospects on the basis of gender. See, e.g., Mississippi Univ. for Women v. Hogan, 458 U.S. 718, 724, 731 (1982) (state must provide "exceedingly persuasive justification" for gender classification).

85. United States v. Paradise, 480 U.S. 149, 167 (1987); id. at 196 (O'Connor, J., dissenting).

86. Compare Paradise, 480 U.S. at $185-86$ ("The race-conscious relief imposed here was amply justified and narrowly tailored to serve the legitimate and laudable purposes of the District Court.") with id. at 197 (O'Connor, J., dissenting) ("Because the Court adopts a standardless view of 'narrowly tailored' far less stringent than that required by strict scrutiny, I dissent."). 


\section{Deterrent Objective of Title VII}

The Supreme Court has identified two fundamental objectives of Title VII. The first objective, to which a preferential remedy is directed, is to eliminate the effects of employment discrimination. The second objective is to provide incentives to "shun practices of dubious legality"-in short, to deter unlawful discrimination. ${ }^{87}$ Systematic compensation for dispreferred individuals would enhance the deterrent effect of preferential remedies.

Without compensation, preferential remedies impose minimal costs on employers. If the preferred employees are less qualified than dispreferreds, a preference plan may impose some loss in productivity on an employer. But for seniority-based decisions, there may be no difference in employees' relative ability to perform a job. It is even possible that laying off more senior and more highly paid dispreferred employees could produce a net savings to an employer. In contrast, an obligation to compensate dispreferreds would provide a substantial financial disincentive to discriminatory conduct. Just as back pay and other compensation to victims of employment discrimination provide deterrent incentives, compensation to dispreferreds would also promote deterrence.

Moreover, courts have been reluctant to employ preferential remedies unless an employer has been recalcitrant in remedying intentional discrimination. ${ }^{88}$ In such situations, where preferential relief is almost certainly permissible, an award of compensation to dispreferreds is particularly appropriate to deter egregious discrimination. It seems perverse to force incumbent employees to bear a substantial portion of the cost of remedying their employer's unlawful conduct only when the employer is most culpable. Section 706(g) of Title VII speaks to this point when it specifies that back pay should be "payable by [the party] responsible for the unlawful employment practice." the statutorily prescribed allocation of remedial costs.

\section{E. Disproportionate Burdens on Lower-Level Employees}

Another reason that compensation would be equitable is that the burdens of preferential remedies fall disproportionately on the least affluent

87. Albemarle Paper Co. v. Moody, 422 U.S. 405, 417 (1975) (backpay award provides deterrent incentive). Lower courts have widely cited this formulation of Title VII's objectives. See, e.g., Thompson v. Sawyer, 678 F.2d 257, 286 (D.C. Cir. 1982) (one purpose of remedy is "discouraging employers from discrimination"); Patterson v. American Tobacco Co., 535 F.2d 257, 270 (4th Cir. 1976) (one purpose of back pay award is "to spur unions, as well as employers, to . . . eliminate unlawful discrimination"); Laffey v. Northwest Airlines, Inc., 567 F.2d 429, 471 (D.C. Cir. 1976) (quoting Moody); United States v. United States Steel Corp., 520 F.2d 1043, 1060 n.1 (5th Cir. 1975) (backpay award "operates as an incentive to voluntary compliance").

88. Blumrosen, Affirmative Action in Employment After Weber, 34 Rutgers L. REv. 1, 41; Edwards \& Zaretsky, Preferential Remedies for Employment Discrimination, 74 MICH. L. REv. 1, 6-7 (1975).

89. 42 U.S.C. $\$ 2000 \mathrm{e}-5(\mathrm{~g})$ (1982). 
and least politically powerful nonminority employees. ${ }^{90}$ Compensation would reduce the losses suffered by these lower-level employees. ${ }^{\text {91 }}$

Generally, judicial enforcement of Title VII is much stricter for unskilled and low-skill jobs than for upper-level employment. ${ }^{22}$ Courts require lower-level employers to show the business necessity or job-relatedness of their employee selection procedures. Under these requirements, a facially neutral selection method must be validated if it has a disparate impact on women or minorities. ${ }^{93}$ This approach has proven effective at increasing opportunities for women and minorities in blue collar and lower-level white collar jobs. In contrast, courts have been reluctant to scrutinize law firm partner selection, ${ }^{94}$ university tenure decisions, ${ }^{95}$ and executive hiring and promotion. ${ }^{96}$ This enforcement bias makes nonminority workers in low-paying manual jobs far more likely than professional or upper-level managers to be affected by preferential remedies. ${ }^{97}$

One might presume that unionized workers in blue collar jobs should

90. See A. Goldman, Justice and Reverse Discrimination 114-15 (1979) (burdens of preferences fall disproportionately on young white males just entering job market); see also Johnson $v$. Transp. Agency, 480 U.S. 616, 677 (Scalia, J., dissenting) (burden of preferential remedies falls on those who are "unknown, unaffluent, [and] unorganized"); Wygant v. Jackson Bd. of Educ., 476 U.S. 267, 281 n.8 (1986) (Powell, J., plurality opinion) (junior union members bear entire burden of preferences).

91. See Bartholet, Application of Title VII to Jobs in High Places, 95 HARv. L. Rev. 945, 948 n.2 (1982) (distinguishing "upper and lower level jobs").

92. See $i d$. at $949,948-50$ ("The courts have tended to show far greater deference to upper than to lower level employers."); id. at 949 n.6 (collecting sources); Note, Title VII and Employment Discrimination in "Upper Level" Jobs, 73 ColuM. L. REv. 1614, 1614 (1973). But see Hopkins v. Price Waterhouse, 825 F.2d 458 (D.C. Cir. 1987) (permitting disparate treatment claim against accounting partnership), cert. granted, 108 S. Ct. 1106 (1988). Although Hopkins offers some hope for upper-level employees, the case involved clear evidence of disparate treatment. Id. at 468. No case has applied to upper-level jobs the more powerful theory of disparate impact.

93. Griggs v. Duke Power Co., 401 U.S. 424, 431 (1971). Validation involves demonstrating by professionally accepted means "that the selection procedure is predictive of or significantly correlated with important elements of job performance." Uniform Guidelines on Employee Selection Procedures, 29 C.F.R. \& 1607.5(B) (1987).

94. See, e.g., Hishon v. King \& Spaulding, 24 Fair Empl. Prac. Cas. (BNA) 1303 (N.D. Ga. 1980), aff'd, 678 F.2d 1022 (11th Cir. 1982), rev'd, 467 U.S. 69 (1984). The Supreme Court reversed the trial court's holding that Title VII was inapplicable to the selection of partners by a law firm, thus allowing the plaintiff to proceed with her claim. Id. at 78. However, as in Hopkins, she must carry the relatively heavy burden of proving disparate treatment.

95. See, e.g., Faro v. New York Univ., 502 F.2d 1229, 1231-32 (2d Cir. 1974) ("Of all the fields, which the federal courts should hesitate to invade and take over, education and faculty appointments at a University level are probably least suited for federal court supervision.").

96. See, e.g., Wheeler v. Armco Steel Corp., 471 F. Supp. 1050 (S.D. Tex. 1979) (accepting relevant experience in traditionally segregated job as qualification without requiring validation).

97. Another reason that the least affluent and least powerful nonminorities suffer the most from preferential relief is that minorities and women work disproportionately in entry-level and low-paying jobs. See U.S. Commission on Civil RIghts, Social Indicators of Equality for Minorities AND WOMEN (1978). See generally Women and the WorkPlace (M. Blaxell \& B. Reagan eds. 1976); Bergmann, Occupational Segregation, Wages and Profit When Employers Discriminate by Race or Sex, 1 E. EcoN. J. 103 (1974). As victims of discrimination advanced to their rightful places in the promotional and seniority system, dispreferred employees at the same level are moved down in the hierarchy. In short, preferences affect the economic peers of discrimination victims. Since women and minorities are found disproportionately in lower-level jobs, dispreferred employees likewise come disproportionately from lower-level jobs. 
be able to protect themselves through collective bargaining and political lobbying. ${ }^{88}$ But such a presumption fails to recognize that union power is in the hands of senior employees whose interests often clash with those of younger workers. ${ }^{99}$ For example, when business is slow, employers may adjust to their reduced need for workers by permanent layoffs, temporary layoffs, work hours reductions, or wage reductions. In unionized industries, these adjustments take place predominantly through temporary layoffs. One commentator has observed that

[A]djustments through layoffs are much more favorable to senior workers than are adjustments through across-the-board reductions in (the growth of) real wage rates or hours worked. Thus, the choice of layoffs in unionized firms appears to reflect a decision-making process under which the interests of senior infra-marginal workers count a great deal. ${ }^{100}$

Furthermore, union activity is in decline. ${ }^{101}$ It would be folly to presume that low-wage nonunion sectors will be protected by union political activity.

98. For example, it is the general policy of federal labor law, which governs the formation and enforcement of collective bargaining agreements, to defer to the bargaining and labor arbitration process. See, e.g., American Tobacco Co. v. Patterson, 456 U.S. 63, 76-77 (1982) (endorsing minimal supervision of collective-bargaining agreements). Employees' only protection under federal labor law from union action imposing disproportionate burdens on a subclass of union members is the ephemcral "duty of fair representation." See Harper \& Lupu, Fair Representation as Equal Protection, 98 Hakv. L. Rfv. 1212, 1214 \& n.11 (1988) ("The Supreme Court's current [duty of fair representation] standard proscribes union decisions that are "arbitrary, discriminatory, or in bad faith." "). However, the Supreme Court has made clear that this deferential policy is inapplicable to bargaining that concerns the rights of individual employees under Title VII. See Alexander v. Gardner-Denver Co., 415 U.S. 36, 51 (1974) ("Title VII ... concerns not majoritarian processes, but an individual's right to equal employment opportunities. . . . [T] he rights conferred can form no part of the collectivebargaining process since waiver of these rights would defeat the paramount congressional purpose behind Title VII.").

99. The discussion of union consent to the layoff protection at issue in Wygant v. Jackson Bd. of Educ., 476 U.S. 267 (1986), revealed some infrequently considered aspects of collective bargaining over employment discrimination remedies. Justice Marshall's dissent asserted that the layoff preference plan at issue should be presumptively permissible because, unlike the plan in Stotts, it commanded "the full agreement of [the] employees." Id. at 296, 300 (Marshall, J., dissenting). He noted the union's ratification "by a majority vote" of the layoff plan and ignored the possibility of selfserving action by both the union and the employer. Id. at 299 ("To petitioners, at the bottom of the seniority scale among white teachers, fell the lot of bearing the white group's proportionate share of layoffs that became necessary in 1982."). The danger of an inequitable distribution of group burdens would be substantially diminished if the layoff plan had called for whites to be chosen for layoff by lot rather than according to relative seniority. But since seniority conferred on a majority of union members immunity from layoff, it was not surprising that a majority ratified the layoff provision of the contract. Id. at 281 n.8 (Powell, J., concurring). Such equivocal "consent" to the burdens of layoffs should not make a racial classification permissible.

100. Medoff, Layoffs and Alternatives Under Trade Unions in U.S. Manufacturing, 69 АM. Econ. Rev. 380, 393-94 (1979).

101. See L. Troy \& N. Shrfi.tn, Union Soukckbook al 3-1 (1988) (Union membership as percentage of nonagricultural civilian employment has fallen from $29 \%$ in 1975 to $19 \%$ in 1984.); J.P.

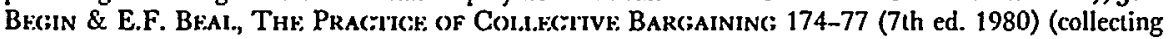
statistics). 


\section{F. Detrimental Reliance}

Dispreferred employees may also assert a claim on the conscience of a court exercising its equitable remedial authority. It is the historic purpose of equity to "secure complete justice." 102 Dispreferred employees have justifiably relied on their employment expectations, foregoing other opportunities during the period of their employment. "Complete justice" requires that this detrimental reliance be protected to the greatest extent that is consistent with the primary statutory objective of remedying employment discrimination. ${ }^{103}$

\section{Implementing Systematic Compensation}

\section{A. Procedure for Awarding Compensation}

The Supreme Court should interpret section 706(g) of Title VII to require that when a court orders preferential relief, it must also order compensation to dispreferred individuals. If the trial court elects not to order compensation, it should have to justify this decision as current doctrine requires for awards of back pay and retroactive seniority under Moody and Franks. ${ }^{104}$ Although systematic compensation should be presumptively appropriate, the Court should recognize an exception when an employer can show that imposing the systematic compensation remedy will cause a financial crisis severe enough to require the company to close the relevant plant. ${ }^{105}$

As early as possible in Title VII litigation, the trial court should encourage the intervention of parties who might be affected by a preferential remedy. ${ }^{108}$ The intervenors need not participate in the liability phase of

102. Brown v. Swann, 35 U.S. (10 Pet.) 497, 503 (1836).

103. See, e.g., Swann v. Charlotte-Mecklenburg Bd. of Educ., 402 U.S. 1, 31 (1971) ("[W]ords are poor instruments to convey the sense of basic fairness inherent in equity."); Hecht Co. v. Bowles, 321 U.S. 321, 329-30 (1944) (Equity is "the instrument for nice adjustment and reconciliation between the public interest and private needs as well as between competing private claims.").

104. See supra notes 25-30 and accompanying text (discussing presumptions established by Moody and Franks).

105. For a discussion of such an imminent bankruptcy exception, see Burke \& Chase, supra note 4 , at 111-15. Burke \& Chase limit their exception from the full payroll remedy to situations in which a firm will have to file for protection under Chapter XI if the remedy is imposed. Id. at 111. This Note's proposed "plant closing" exception recognizes that the effect on workers of a plant closing is equally severe.

106. See FED. R. GIv. P. 24(a) ("[A]nyone shall be permitted to intervene in an action ... [when] the disposition of the action may as a practical matter impair or impede his ability to protect that interest."). Although the Federal Rules only explicitly permit intervention, court activism in seeking potential parties is an accepted part of both class action litigation and judicial review of the proposed terms of consent decrees. See Rutherglen, Notice, Scope, and Preclusion in Title VII Class Actions, 69 VA. L. REv. 11, 83 (1983) (Title VII class action certification should include notice to class members with accompanying right to "opt out"); Schwarzschild, Public Law by Private Bargain: Title VII Consent Decrees and the Fairness of Negotiated Institutional Reform, 1984 DuKE L.J. 887,933 \& n.218 ("In numerous cases, the comments and objections of third parties have in fact evoked modifications of consent decrees."). 
the trial, but their early intervention ensures that settlement negotiations will include representatives of all interested parties. Moreover, multiparty litigation will more accurately reflect the actual structure of the dispute. ${ }^{107}$

The most common form of compensation to dispreferreds should be front pay. ${ }^{108}$ Front pay consists of paying an employee who, for example, has been denied a promotion the wage she would have received had she been promoted. Courts currently award front pay to plaintiffs when there are no positions available without bumping incumbent employees. ${ }^{100} \mathrm{Cal}-$ culating and supervising an award of front pay to dispreferreds should be well within the capacity of district courts.

\section{B. Objections to Compensation}

In the debate over the permissibility of preferential remedies, courts and commentators have often argued that without preferential relief, the purpose of Title VII would be substantially frustrated. ${ }^{110}$ On this view, complete justice requires the present use of race and gender preferences to overcome the lingering effects of past discrimination. Since the cost of systematic compensation would make employers more likely to resist the imposition of preferential relief, one may raise a similar objection to compensation. ${ }^{111}$

There can be no doubt that employers who currently acquiesce in court-ordered preference plans as a cost-effective litigation strategy would reexamine this practice were they liable for compensation to dispreferreds. ${ }^{112}$ But this effect must be weighed against the beneficial incentives of systematic compensation. First, employers would have an additional incentive to defend and improve the qualifications of their minority and fe-

107. In providing compensation, courts also must determine who is entitled to compensation. Courts have substantial experience with causation analysis under Title VII, and these causation standards are equally applicable to dispreferreds. The proper analysis would follow the disparate treatment theory of McDonnell Douglas as Justice Brennan suggested in Johnson v. Transportation Agency, 480 U.S. 616, 626 (1987).

108. For an example of the application of the front pay remedy, see Thompson v. Sawyer, 678 F.2d 257 (D.C. Cir. 1982). See generally Note, Front Pay-Prophylactic Relief Under Title VII of the Civil Rights Act of 1964, 29 VAND. L. REv. 211 (1976).

109. See, e.g., Thompson v. Sawyer, 678 F.2d 257, 292-93 (D.C. Cir. 1982) (upholding award of front pay); Patterson v. American Tobacco Co., 535 F.2d 257, 269 (4th Cir. 1976) (approving award of front pay); Bush v. Lone Star Steel Co., 373 F. Supp. 526, 538 (E.D. Tex. 1974) (awarding front pay).

110. This argument figured prominently in United Steelworkers v. Weber, 443 U.S. 193, 201-02 (1979) (prohibition of "race-conscious affirmative action would "bring about an end completely at variance with the purpose of the statute' and must be rejected") (quoting United States v. Public Util. Comm'n, 345 U.S. 295, 315 (1953)).

111. See, e.g., Comment, supra note 4, at 370 (compensation "could impede or halt the use of preferential remedies").

112. An obligation to compensate dispreferreds probably would cause employers to resist the imposition of preferential relief more than they do now. However, to the extent that courts restrict their use of preferential relief because of its effects on dispreferreds, the mitigation of those effects might lead to more extensive use of such remedies. 
male employees. No compensation must be paid when nondiscriminatory selection criteria indicate that minority and female employees are the most qualified. Employers, therefore, would benefit from changing their selection criteria to attach greater weight to characteristics on which minority and female candidates excel.

Another benefit would be increased investment in recruitment, job training, training for supervisors, community outreach, and other efforts to increase minority and female employment that do not require incumbent employees to bear direct remedial costs. ${ }^{113}$ An increased incentive to expand the pool of qualified minority and female workers, to combat racism and sexism among supervisors and other employees, and to improve the skills of minority and female employees would promote the goals of Title VII far more effectively than does widespread "hiring by the numbers." Finally, compensation reduces the possibility that parties to employment discrimination litigation will succeed in imposing a substantial portion of remedial costs on dispreferred individuals. When the interests of both plaintiffs and defendants are served by placing these costs disproportionately on junior lower-level employees, ${ }^{114}$ the outcome of litigation can be a regressive and inefficient distribution of the remedial burden. Systematic compensation ameliorates the effect of this burden on dispreferred individuals.

It is also appropriate to ask who will ultimately bear the burden of systematic compensation. ${ }^{116}$ The incidence of remedial costs will depend on the employer's degree of market power. ${ }^{116}$ If the employer is organized as a corporation, stockholders will bear the portion of remedial costs that cannot be passed on to consumers, workers, and managers. ${ }^{117}$ Whatever the exact distribution of costs within the market, it would be difficult to

113. A job training program targeted for entry-level postions could allow employers to increase minority and female employment without using a preference plan. Since women and minorities are employed disproportionately in lower-level positions, such a facially neutral training program could provide greater than proportional benefits to those groups (and incidentally benefit nonminority lower-level individuals). It is virtually certain that the choice to institute a training program restricted to lower-level positions would survive challenge under the disparate impact strand of Title VII doctrine.

114. See supra note 109 and accompanying text (discussing political power of more senior union members).

115. Of course, this question of the incidence of costs is equally applicable to analysis of ordinary liability under 'Title VII.

116. Market power, in this context, refers to the employer's ability to affect the relevant market price by altering the quantity it supplies (in the product market) or demands (in the labor market).

117. The less market power the firm has, the greater the portion of costs which will be borne by the residual claimants-stockholders. As the firm's power in its product market increases so does the customer's share of remedial costs. Increased firm power in the labor market increases the degree to which workers generally bear costs. Finally, managers will pay a portion of remedial costs when they have profit-sharing agreements with the firm. Shareholders bear the residual costs of remedies just as they reap the residual benefits of the firm's success. For example, a firm that sells its products and buys its labor in perfectly competitive markets will be unable to pass on any compensation costs to customers or workers because any increase in the firm's product price would cause it to lose all of its business and any decrease in wages would result in the immediate departure of all workers. 
frame an argument for the proposition that incumbent employees should bear remedial costs rather than customers, shareholders, or managers. ${ }^{118}$ In choosing to allocate costs among customers, shareholders, and managers, the most desirable distribution would focus these costs on managers and shareholders since they presumably control the discriminatory employment practices.

\section{ConCLUSION}

The permissibility of preferential employment discrimination remedies is one of the most controversial legal issues of the day. ${ }^{119}$ The Supreme Court's approach to these cases has vacillated between asserting the primacy of the need for complete relief and seeking ways to protect the interests of incumbent employees. Compensation to dispreferred employees acknowledges the saliency of both the discrimination victim's remedial entitlement and the incumbent employee's legitimate expectations. While compensation is surely no panacea, at the very least, the economic, moral and legal arguments for compensation illuminate some often neglected issues concerning the use of preferential remedies. Systematic compensation to dispreferreds offers the Court a much-needed mediating response to the deep conflicts of interests and ideals that arise in remedying employment discrimination.

118. The "clean hands" doctrine should prevent incumbent employees who were personally involved in the discriminatory practice from receiving the benefit of systematic compensation. See Precision Instrument Mfg. Co. v. Automotive Maintenance Mach. Co., 324 U.S. 806, 815 (1945) ("This maxim necessarily gives wide range to the equity court's use of discretion in refusing to aid the unclean litigant.").

119. Despite the weight of judicial opinion and academic commentary that currently supports the use of preferential remedies, a recent public opinion survey found that $80 \%$ of whites and $50 \%$ of blacks opposed granting job preferences to qualified blacks to compensate for past discrimination. Black and White: A Newsweek Poll, Newsweek (Mar. 7, 1988). 
